\title{
ANALYSIS OF POSSIBILITY OF USING NEURAL NETWORK TO FORECAST PASSENGER TRAFFIC FLOWS IN RUSSIA
}

\section{T. O. Blinova}

Department of Aeromechanics and Flight Engineering, Moscow Institute of Physics and Technology (State University), Russia, Moscow Region, Zhukovsky, Gagarina St., 16. E-mail: blinova-to@yandex.ru

Received 2006-11-15, accepted 2007-03-20

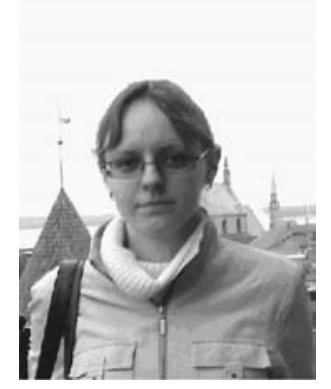

Tatiana O. BLINOVA, BSc

Date and place of birth: January 1985, Moscow Region, Russia.

Education: 2006 - Moscow Institute of Physics and Technology (State University), Department of Aeromechanics and Flight Engineering, bachelor's degree in applied physics and mathematics.

Affiliations and functions: 2006 - Central Institute of Aerohydrodynamics (TsAGI), practical training.

\begin{abstract}
At present the problem of forecasting passenger transport demand is of immense importance for air transport producers as well as for investors since investment efficiency is greatly affected by the accuracy and adequacy of the estimation performed. The aim of the present research is to analyze the possibility of using a neural network approach to forecast the expansion of the airtransport network in Russia.

The neural network model that has been developed to forecast passenger traffic flows includes 28 time-lagged feed-forward artificial neural networks. The number of the neural networks corresponds to the forecasted number of intraregional and interregional passenger traffic. The relative forecasting error for these neural networks at the adaptation stage is less then $5 \%$.

Analyses of the forecast of intraregional and interregional passenger traffic for 2006-2010 proved that the neural model developed adequately described the passenger traffic demand for the next two or three years. The model can therefore be used for short-term forecasts of the Russian air transport network.
\end{abstract}

Keywords: air passengers traffic structure, forecasting, neural network, OD-matrix.

\section{Introduction}

While making plans for future action in the field of passenger-carrier aviation, it is essential to have an idea of what the demands concerning the fleets of aircraft will be. This idea should be based on a well-grounded forecast of the development of the air transport market. The prediction ought to consider not only the capacity of the future market, but also its structure [6].

For making a forecast of the market of air passenger transportation are used multi-regression and gravity models [5]. However, these models do not take into account the process of topology changes in the air transportation network, the development of the structure of the corresponding flows of passenger traffic, or the interdependence of passenger traffic flows.

The purposes of the present research are to analyze the possibility of using a neural network approach to forecast the development of the Russian air transportation network and to design a neural network model of forecasting the development of intraregional and interregional passenger traffic flows in Russia.

\section{Methods applied}

Neural networks are a universal tool for data processing. Their application is especially important when the task given is complicated by the following: the absence of physical or statistical understanding of the problem, statistical dispersal of the data observed, and a nonlinear mechanism that is responsible for data generation ${ }^{1)}$. The development of the theory and methods of neural network programming resulted in the design of a number of different types of neural networks for the solution of various problems ${ }^{2)}$ [1].

The choice of a neural network model for the solution of one problem or another is determined by the

\footnotetext{
1) ХАЙКИН, С. Нейроннье сети: полный курс. Второе издание. Изд. Дом «Вильямс», 2006.

2) ЕЖОВ, АА.; ШУМСКИЙ, СА. Нейрокомпьютинг и его применения в экономике $и$ бизнесе. Серия "Учебники экономико-аналитического института МИФИ". Под ред. проф. В.В. Харитонова. М.: МИФИ, 1998.
} 
architectural features and the method of training the neural network. According to the type of training and the type of network architecture, the classification of basic neuroarchitecture first introduced by Bart Kosko can be mentioned (Tab 1) [7].

Table 1. Classification of Bart Kosko

\begin{tabular}{|c|c|c|}
\hline $\begin{array}{c}\text { Type of learning } \\
\text { Type of network } \\
\text { architecture }\end{array}$ & By teacher & Without teacher \\
\hline Feed-forward & $\begin{array}{c}\text { Multi-layer perceptron } \\
\text { (function approximation, classification) }\end{array}$ & $\begin{array}{c}\text { Kohonen self-organizing network, Emulative } \\
\text { network } \\
\text { (data compression, feature extraction) }\end{array}$ \\
\hline \hline Feedback & $\begin{array}{c}\text { Recurrent approximator } \\
\text { (forecast time series, on-line training })\end{array}$ & $\begin{array}{c}\text { Hopfield network } \\
\text { (associative memory, data clustering, } \\
\text { optimization) }\end{array}$ \\
\hline
\end{tabular}

The main types of neural networks are assigned to the cells depending on the presence of feedback and the method of training. Tasks types indicated in parentheses are solved by means of the given type of neural network.

The introduction of the "time" parameter in the operation of a neural network allows statistical variations in nonstationary processes to be taken into account. Two types of neural network are used for time data handling: recurrent networks and the time-lagged feed-forward network [8].

Shown in the figure 1 is "the focused time-lagged feedforward network" embodied by multi-layer perception.

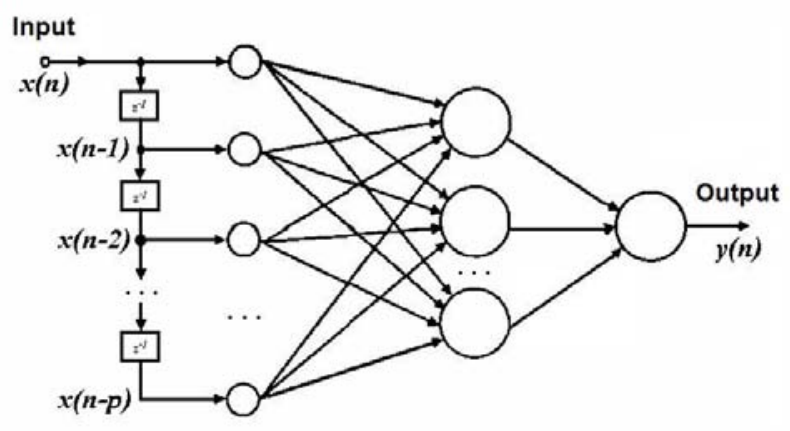

Fig 1. The focused network time-lagged feed-forward network embodied by multi-layer perception

In this network, the short-term memory is concentrated in the input layer of neurons, which simplifies its construction. The training of such a network is realized by standard error back-propagation algorithm.

For describing a transport network, an OD-matrix is used [2, 3, 4]. Each cell of the matrix represents transport flow on a corresponding OD-pair — "origin-destination pair" (Tab 2).

The sequence of OD-matrixes corresponding to the consistent time lags allows the development of demand structure for passenger air traffic to be described and changes in the structure of passenger air traffic flows to be showed.

For regular long-haul transportation of air passengers, domestic Russian airlines use 144 airports located in 140 cities of the country. Only long-haul and regional aircraft for domestic long-haul (intraregional and interregional) airlines are considered in this paper. Routes to airports in foreign countries and local airlines are excluded.

Table 2. OD-matrix, $X_{i}$ - origin, $X_{j}-$ destination, $u_{i j}-$ flow between $X_{i}$ and $X_{j}$

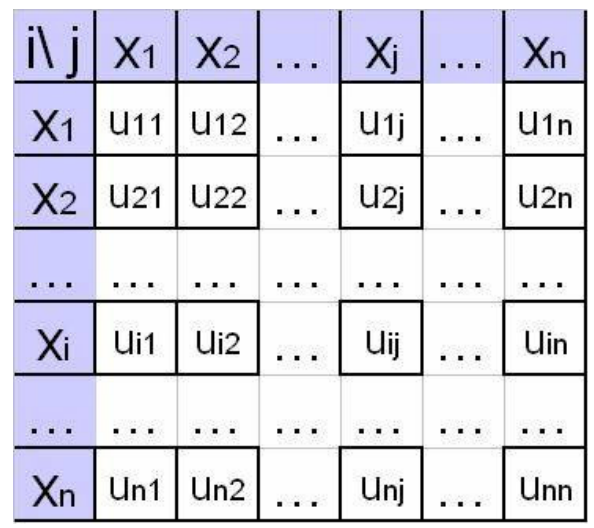

Table 3. Matrix of intraregional and interregional passenger traffic flows

\begin{tabular}{|l|l|l|l|l|l|l|l|}
\hline \multicolumn{1}{|c|}{ FD RF } & FAR EAST & VOLGA & NORTHWEST & SIBERLAN & URALS & CENTRAL & SOUTH \\
\hline FAR EAST & & & & & & & \\
\hline VOLGA & & & & & & & \\
\hline NORTHWEST & & & & & & & \\
\hline SIBERIAN & & & & & & & \\
\hline URALS & & & & & & & \\
\hline CENTRAL & & & & & & & \\
\hline SOUTH & & & & & & & \\
\hline
\end{tabular}

To simplify data analysis, a matrix of intraregional and interregional passenger traffic flows is considered. Its dimensions are $7 \times 7$ (Tab 3) according to the number of federal districts in the Russian Federation (Fig 2).

The corresponding 14 OD-matrixes with the dimension $7 \times 7$ were obtained by TsAGI collaborators of the Department of Strategic Researches on the basis of the data of flight timetables of aircraft for long-haul airlines of the Russian Federation from 1992 till 2005.

As interregional passenger traffic flows to the destination and back are almost the same, the converted matrix is of triangular form and is the result of its averaging. This permits the vector length of the basic data at the input in the neural network to be substantially reduced to 28 . 


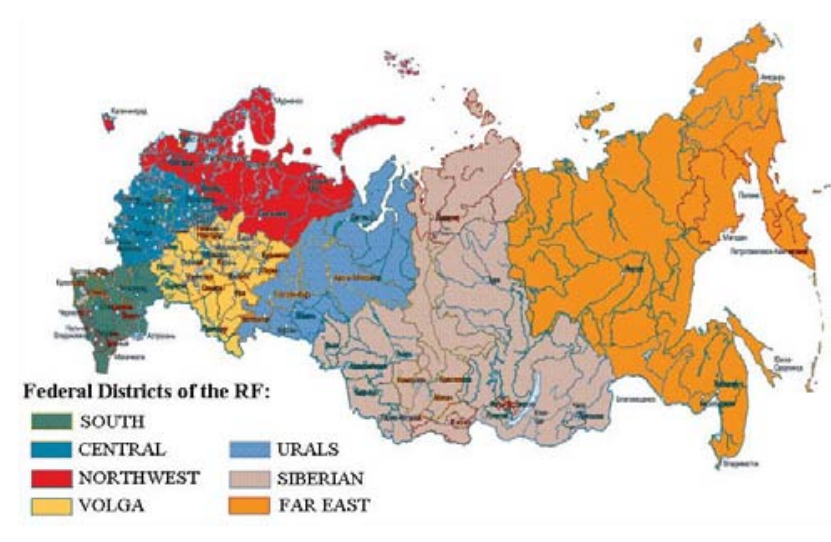

Fig 2. Federal districts of the Russian Federation

In the context of a neural network approach, a few versions of modeling the forecasting of the development of the passenger traffic structure could be used for the network concerned (Fig 3). Either of the versions supposes the use of various types of neural network architecture.

Versions b), c) and d) are extrapolation problems. Version a) is an explicit approximation problem.

Versions a), b) and d) require the presence of data in addition to the OD-matrix set about factors determining the development of the air transport net. The preparation of this data requires a huge amount of work for gathering, handling and presentation information.

Version c) is therefore used for the solution of the forecasting problem in this work, since only the consistent set of OD-matrixes of intraregional and interregional passenger traffic flows is necessary.

As a model of the neural network created, the focused time-lagged feed-forward network embodied by multi-layer perception is chosen.

For each passenger traffic flow (one of 28), a neural network is produced. The general form of architecture is shown in the picture (Fig 4).

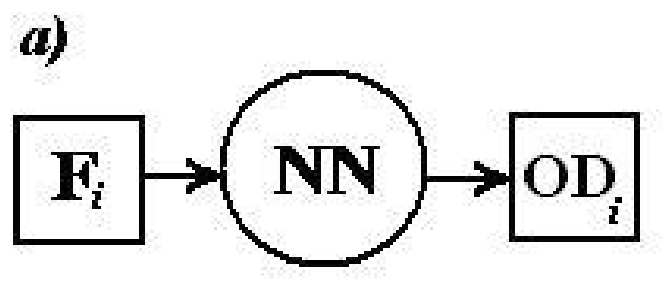

c)

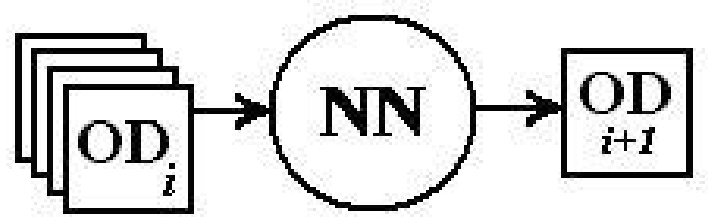

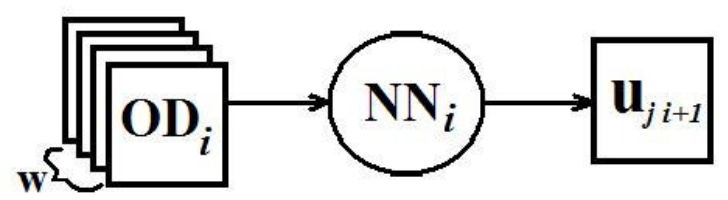

Fig 4. General form of architecture, $j=1, \ldots, 28$

$W$ OD-matrixes for $w$ previous years are in the input of the net. The corresponding passenger traffic flow is in the output. Since the training set in the particular problem is not large enough, the early stopping method of training is used; the session of learning from some point of time occasionally stops in several epochs. After that the network is tested by a validation subset. Such a procedure enhances the efficiency of generalization in comparison with exhaustive learning (where the whole set of examples is used without stopping the session).

MATLAB is used as the programming environment.

\section{Analysis of results}

Analysis of the results shows, that the type of forecasting curves is not always satisfactory and not for each pair of administrative districts. ("Satisfactory" means suitable speculative and intuitive concepts about the possible development of the structure of passenger traffic flows within the next few years). Specific curves of "satisfactory" and "unsatisfactory" forecasts are shown in figure 5 .

The statistics of passenger traffic flows are represented with a solid line. The values of passenger traffic flows obtained by the neural network model of forecast are represented by a dotted line.
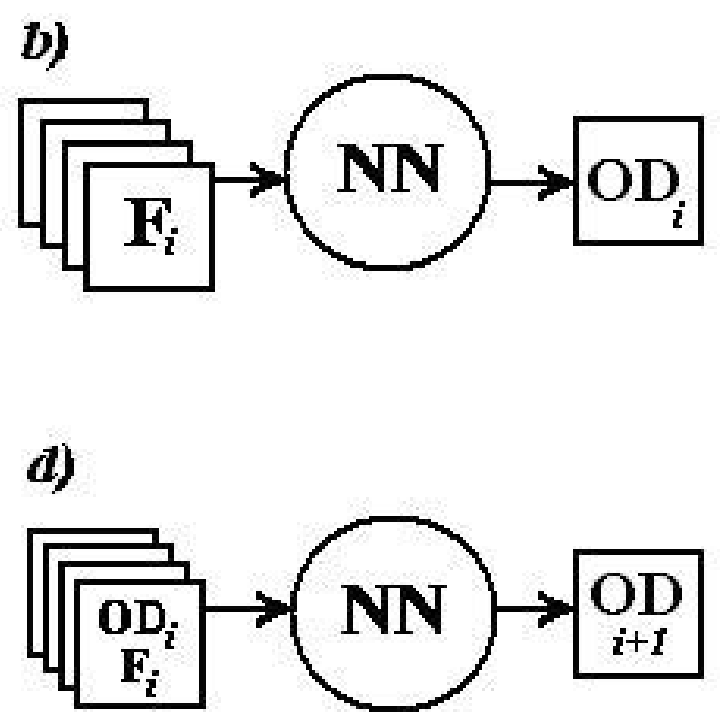

Fig 3. A few versions of the formalization of forecasting the development of the passenger traffic structure, $\mathrm{F} i$ - a range of factors characterizing the system in the $\mathrm{i}$-th moment $\mathrm{OD} i$ - a matrix, characterizing the system in the $\mathrm{i}$-th moment 


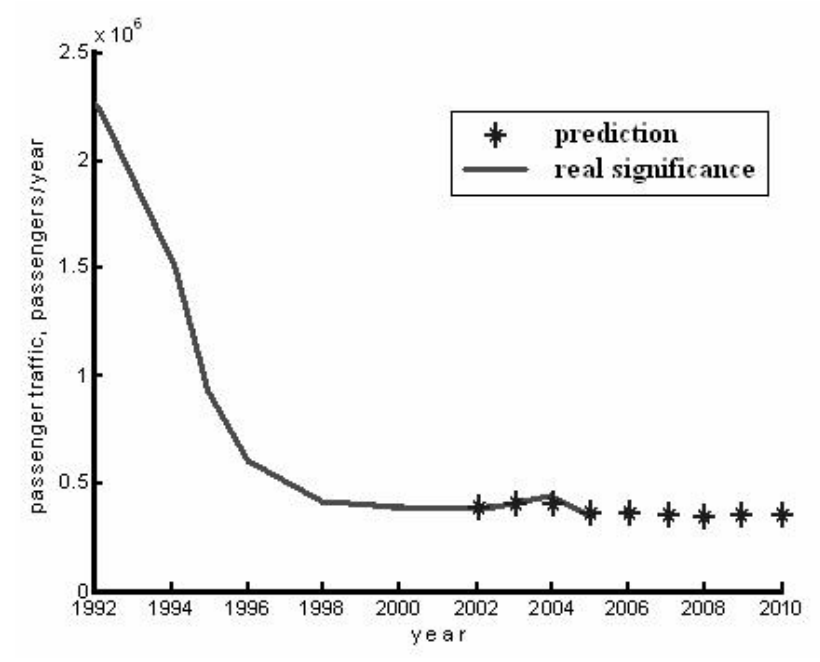

Fig 5. "Satisfactory"

For values of passenger traffic flows that smoothly change over time, the neural network model gives a "satisfactory" result.

For values of passenger traffic flows that have abrupt variations through the years, the neural network model gives an "unsatisfactory" forecast of the development of passenger traffic flows due to insufficient generalization of the neural network.
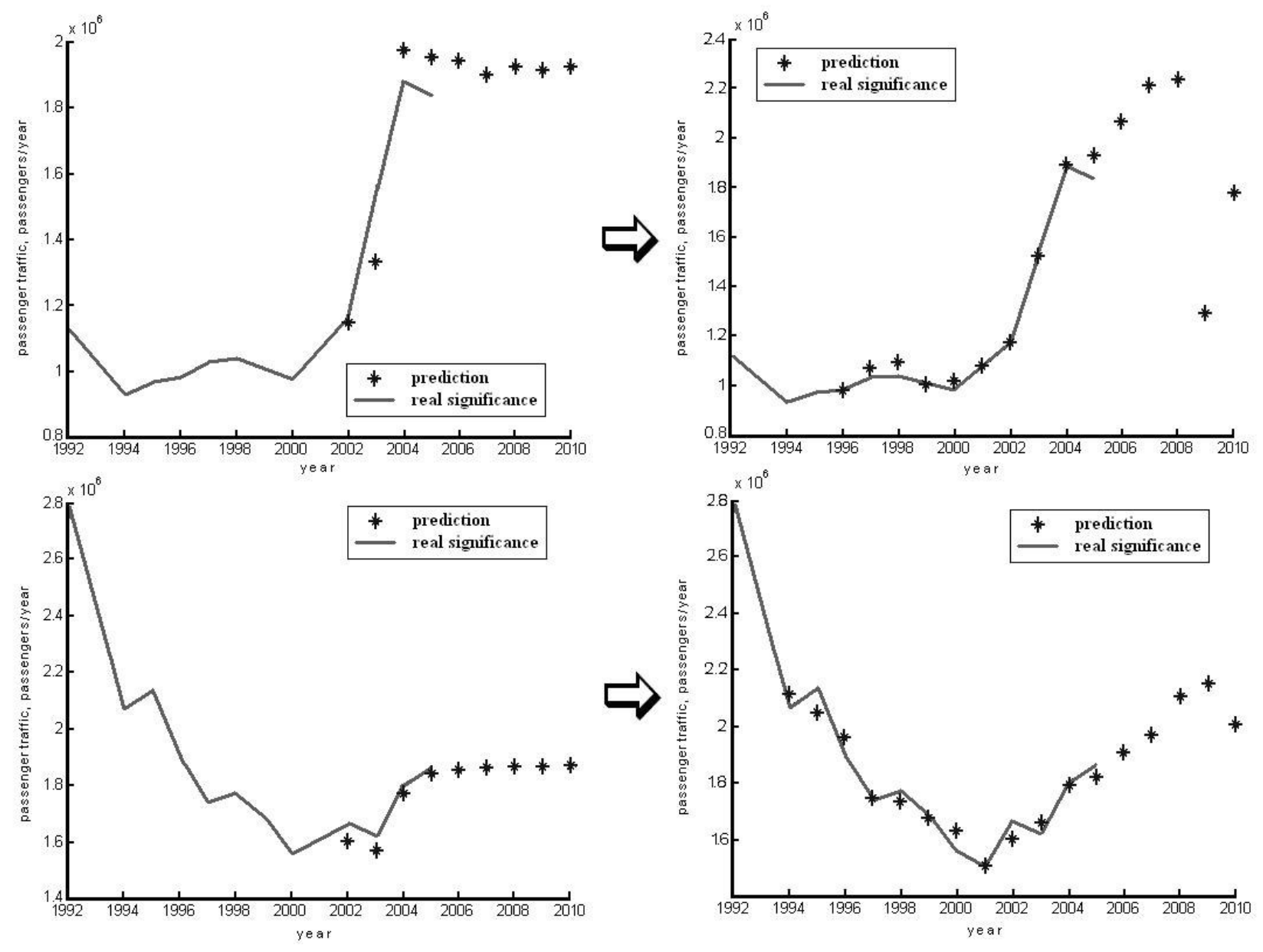

The improvement of the generalizations of a number of neural networks giving "unsatisfactory" forecasts was made by means of the method of automatic bayes regularization. The examples of such improvement are shown in figure 6 . To improve the neural network model generalization for more than the nearest three years was impossible.

Fig 6. The improvement of the generalization 
From the Volga region

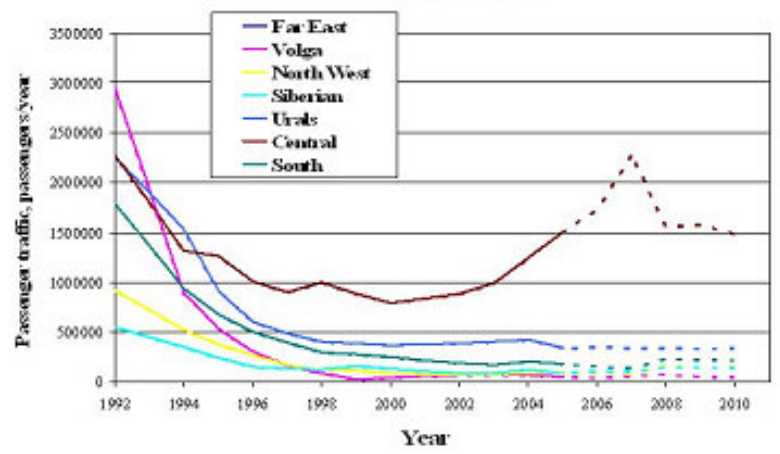

From the North West region

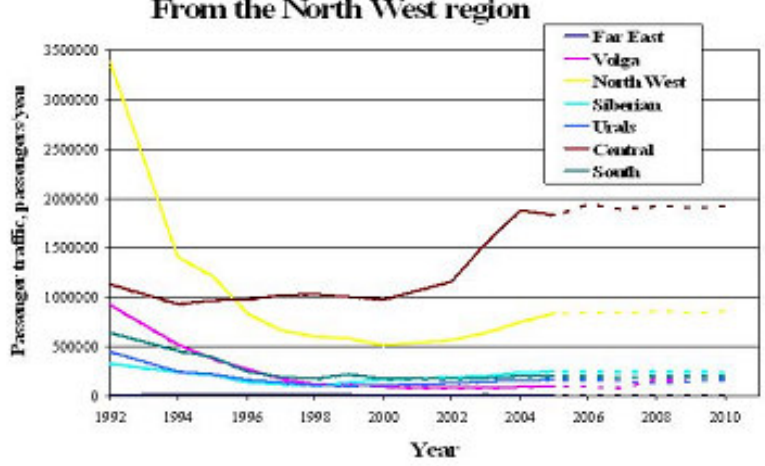

From the Lrals region

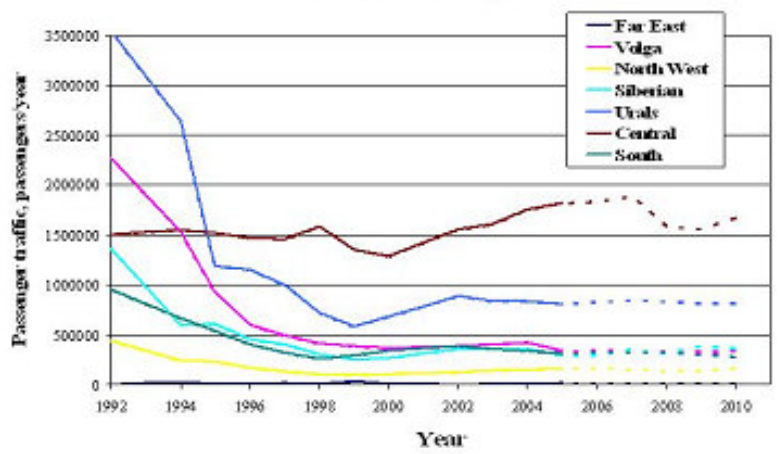

From the Siberian region

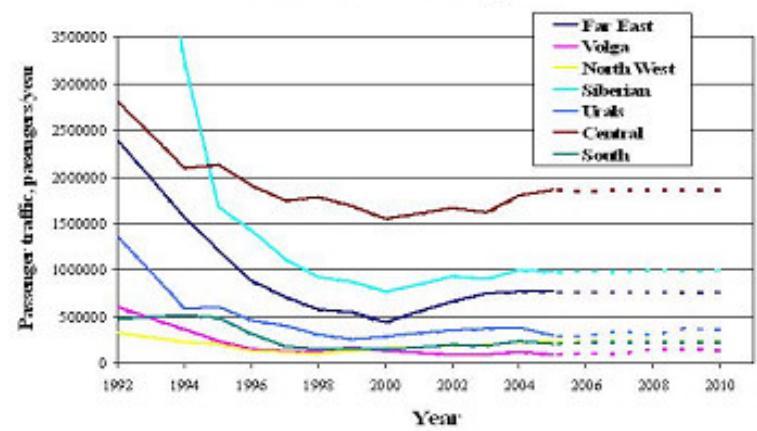

Fig 7. Forecast calculation of passenger traffic values

The analyses of the forecast calculation of passenger traffic values for 2005-2010 showed that the development behavior and the topology of domestic air transport in Russia correspond to the trends of air transport system development existing in the past several years in this country (Fig 7).

These trends are primarily caused by:

- the continuation of passenger air traffic flows between the Central and other federal districts (centralization of air transport), although not so considerable as in previous years (Fig 8);

\section{From the Central region}

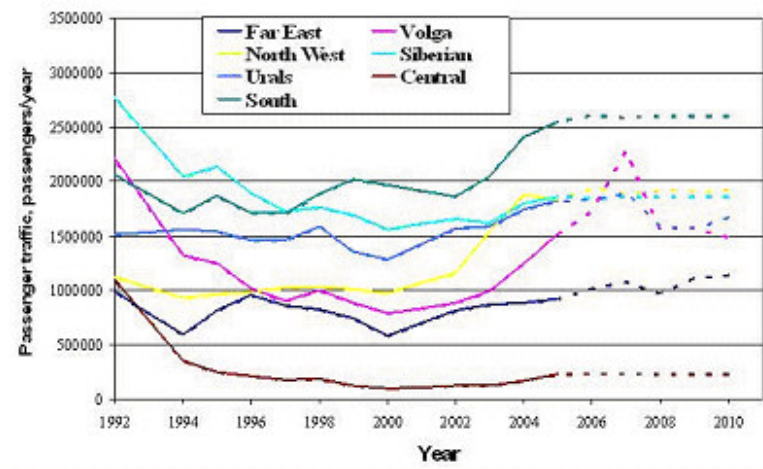

Fig 8. Passenger traffic from the Central region

- the conservation of instability of passenger traffic flows between the Far East and the Volga, between the Far East and the Urals, and between the Far East and the Northwest federal districts (Fig 9-10);

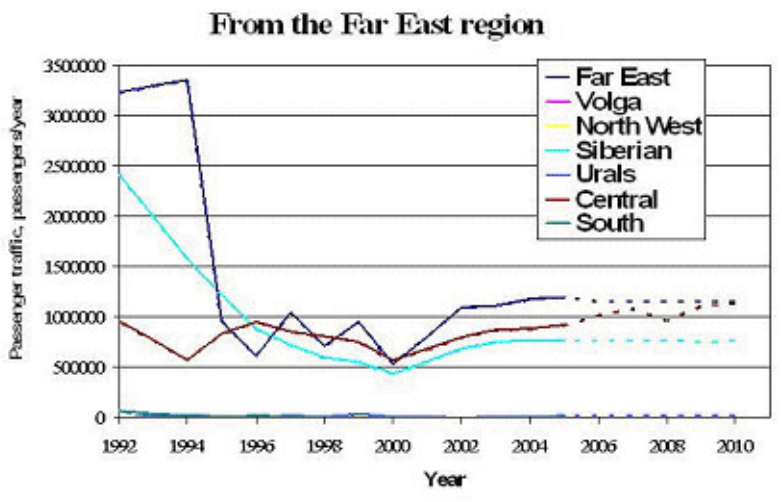

Fig 9. Passenger traffic from the Far East region

From the Far East region

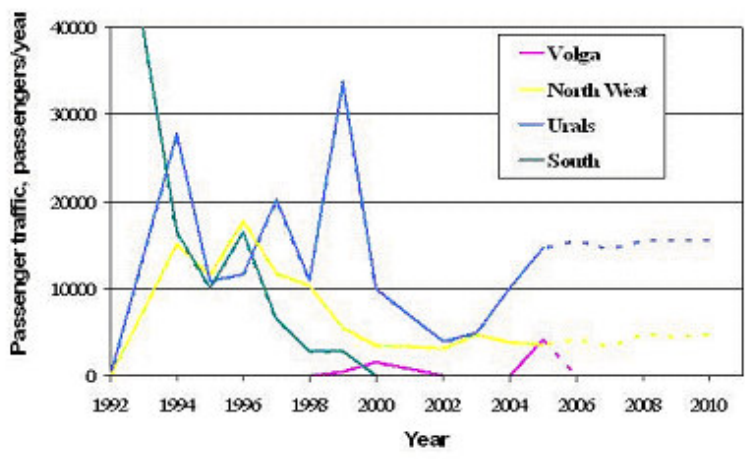

Fig 10. Passenger traffic from the Far East region 


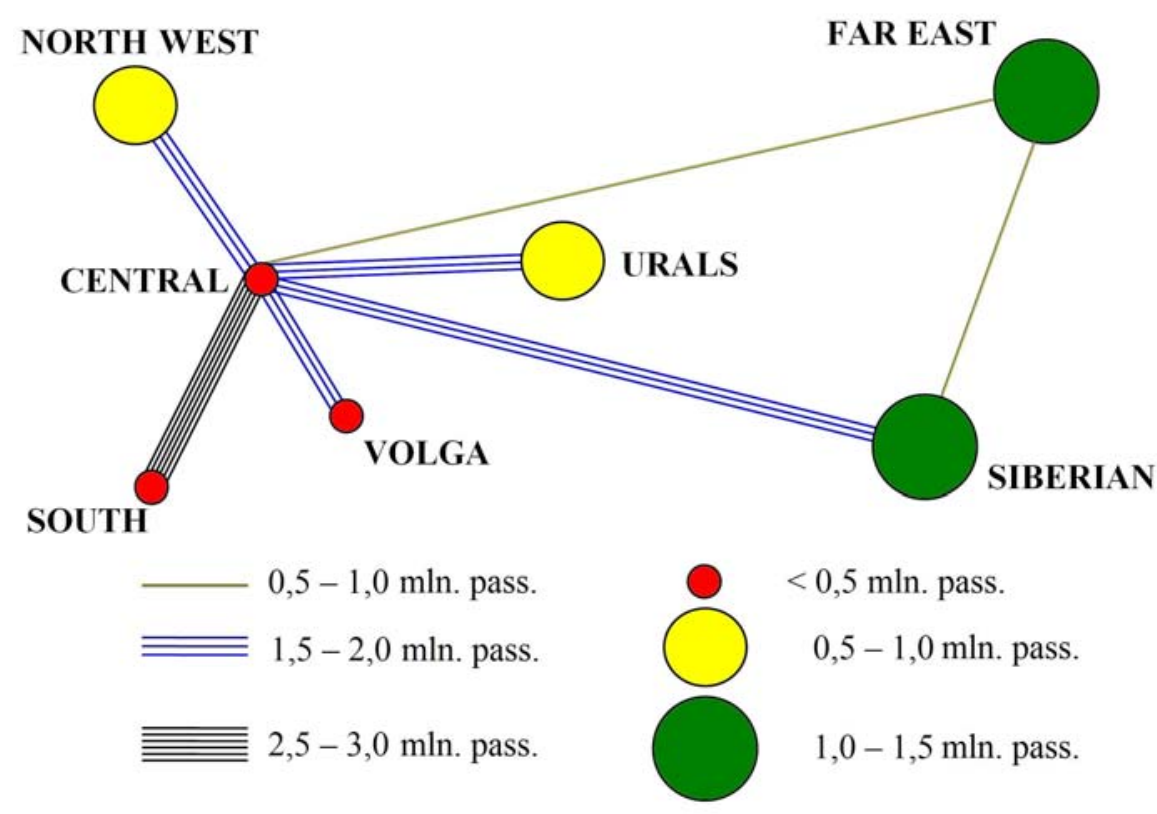

Fig 12. The structure of dominant passenger traffic flows within Russia

- the continued stagnation of intraregional passenger traffic flows in practically all regions, especially in the Central, in Volga and Northwest federal districts (see Fig 11).

\section{Intraregional passenger traficic}

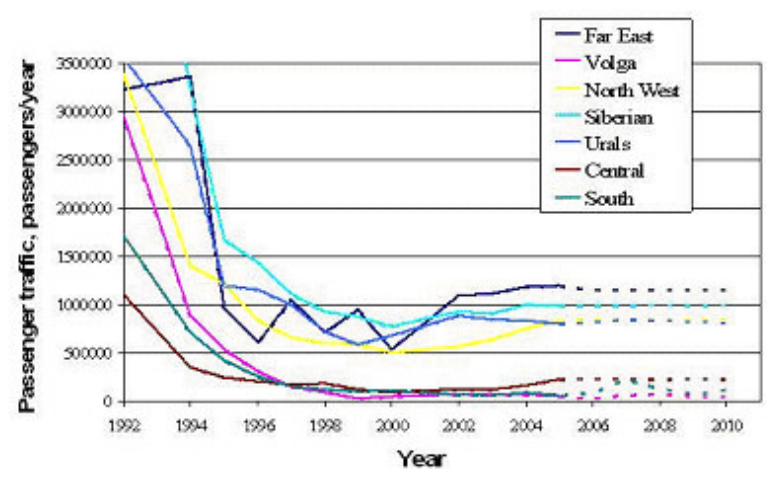

Fig 11. Intraregional passenger traffic

The structure of dominant passenger traffic flows within Russia is shown in figure 12. It is possible to note that the neural network model sufficiently describes the development of intraregional and interregional air passenger traffic in the Russian Federation for the years immediately ahead.

Summing the forecasting values of limiting passenger traffic flows for each pair of federal districts, the forecast of general limiting passenger traffic flow within Russia for the years immediately ahead can be obtained (Fig 13). The growth rate will be $6.2 \%$ in 2006 in comparison with 2005, $2.7 \%$ in 2007 in comparison with 2006 and $10.0 \%$ in 2008 in comparison with 2007.

The neural network model developed adequately describes the structure of passenger traffic flows forecasting for the two (maximum three) years immediately ahead and could be used for a short-term forecast of the development of the air transport net in the Russian Federation.

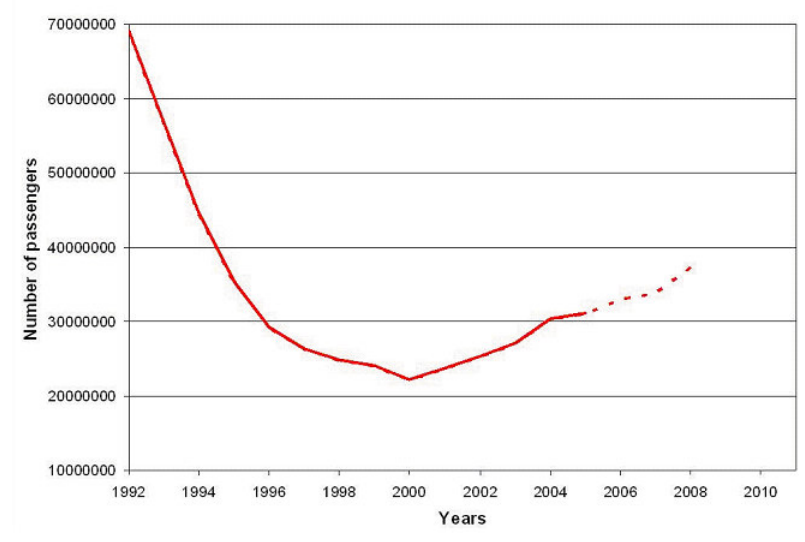

Fig 13. Passenger traffic flow

\section{Conclusions}

- The problem considered in this paper of forecasting the structure of the flow of passenger traffic between the regions (administrative districts) of Russia, is the initial stage in the creation of a model to forecast the development of the air transport network in Russia. At this point, the possibility of using a neural network programming method was investigated. This method permits taking into account a number of the features of the development of the air transport network, particularly the interdependence of passenger traffic flows and the topology changes of airline networks over time. 
- $\quad$ The neural network model that was developed to forecast passenger traffic flows includes 28 timelagged feed-forward artificial neural networks. The number of neural networks corresponds to the forecasted number of intraregional and interregional passenger traffic. The relative forecasting error at the adaptation stage for the neural networks created is less then $5 \%$.

- Analyses of the forecast of intraregional and interregional passenger traffic for 2006-2010 proved that the neural model developed adequately describes passenger traffic demand for the next two or three years. The model can therefore be used for shortterm forecasts of the Russian air transport network.

- The continuation of investigations could be connected with the perfection of the forecasting model, with the change in the model of the neural network in use, and with the replacement of the investigation paradigm, which would include the use of the data approximation problem instead of the extrapolation problem.

\section{References}

1. ALEKSEEV, KPG.; SEIXAS, JM. Forecasting the air transport demand for passengers with neural modeling. In Neural Networks. Proceedings of VII Brazilian Symposium on Neural Networks, 2002, p. 86-91.

2. MATHIAS, P.; FELLENDORF, M.; VORTISCH, P. Monet: Dynamic network modeling in transport systems. In Website: http://www.ptvamerica.com/docs/2000\%20MON ET\%20VISUM\%20online.pdf.
3. RUAN, S.; McCORD, M.; GOEL, PK. et al. Estimation of original-destination matrix using link flow information from groundbased and satellite and airborne sensors. In Website: http://www.stat.osu.edu/ ruan/OD_estimation.p $d f$.

4. SUN, C. Dynamic origin/destination estimation using true section densities. In Website: http://www.path.berkeley.edu/PATH/Publication s/PDF/PRR/2000/PRR-2000-05.pdf.

5. БАЛАШОВ, ВВ.; СВИРИДЕНКО, ЕА.; СМИРНОВ, АВ. et al. Вопросы прогнозирования спроса на пассажирские авиаперевозки. In Современный инновационный менеджмент. Концепции. Модели. Оценки. Под ред. ПА. Нечаева, ЛН. Сухановой. /Федер. агентство по образованию. М.: Экостар, 2006, с. 9-25.

6. БАЛАШОВ, ВВ.; СВИРИДЕНКО, ЕА.; СМИРНОВ, А.В. et al. Исследование тенденций развития авиатранспортной системы России. In Проблемы создания перспективной авиационно-космической техники. Физматлит, 2005, с. 46-59. 